\title{
Adenosine 3'-phospho 5'-phosphosulfate Transporter 1
}

National Cancer Institute

\section{Source}

National Cancer Institute. Adenosine 3'-phospho 5'-phosphosulfate Transporter 1. NCI Thesaurus. Code C122737.

Adenosine 3-phospho 5-phosphosulfate transporter 1 (432 aa, $\sim 48 \mathrm{kDa}$ ) is encoded by the human SLC35B2 gene. This protein plays a role in adenosine 3'-phospho 5'phosphosulfate (PAPS) transport. 